\title{
THE EFFECT OF A SUPERPLASTICIZER ADMIXTURE ON THE MECHANICAL FRACTURE PARAMETERS OF CONCRETE
}

\author{
VPLIV DODATKA SUPERPLASTIFIKATORJA NA PARAMETRE \\ MEHANSKEGA ZLOMA BETONA
}

\author{
Hana Šimonová, Ivana Havlíková, Petr Daněk, Zbyněk Keršner, Tomáš Vymazal \\ Brno University of Technology, Faculty of Civil Engineering, Veveří 331/95, 60200 Brno, Czech Republic \\ simonova.h@fce.vutbr.cz
}

Prejem rokopisa - received: 2014-07-23; sprejem za objavo - accepted for publication: 2014-09-03

doi:10.17222/mit.2014.114

\begin{abstract}
This paper focuses on the mechanical fracture parameters obtained from records of three-point bending tests on concrete specimens with a central edge notch. The tests were conducted on four sets of specimens made of different materials. The concrete of the specimens was different in the dosage of Portland cement CEM I $42.5 \mathrm{R}\left(305 \mathrm{~kg} / \mathrm{m}^{3} \mathrm{or} 355 \mathrm{~kg} / \mathrm{m}^{3}\right)$ and superplasticizer (none or $0.25 \%$ of the mass of the cement). The consistency class of fresh concrete determined using a slump test and a flow-table test was the same for all the mixtures. Three specimens in each set were tested after aging for $28 \mathrm{~d}$. Increasing the dosage of cement and superplasticizer admixture influences the mechanical fracture properties of the concrete in both positive and negative ways. It follows that it is proper to monitor not only the effect of the superplasticizer admixture on the compressive strength values, but also focused attention on the fracture parameter values. The resistance to stable and unstable crack propagation, which is evidently connected with the durability of material, was quantified using a double- $K$ fracture model.
\end{abstract}

Keywords: concrete, mechanical fracture parameters, superplasticizer, fracture test, double- $K$ model

V tem članku se avtorji osredinjajo na parametre mehanskega zloma, ugotovljene pri tritočkovnem upogibnem preizkusu vzorcev iz betona s sredinsko zarezo na robu. Preizkusi so bili izvršeni na štirih serijah vzorcev z razliko v materialu. Beton vzorcev se je razlikoval v dodanem Portland cementu CEM I 42,5 R $\left(305 \mathrm{~kg} / \mathrm{m}^{3}\right.$ ali $\left.355 \mathrm{~kg} / \mathrm{m}^{3}\right)$ in superplastifikatorju (z masnim deležem $0,25 \%$ cementa ali brez njega). Razred konsistence svežega betona, določen s preizkusom posedanja in preizkusom tečenja na mizi, je bil enak za vse mešanice. Iz vsake serije so bili preizkušeni trije vzorci, stari 28 d. Naraščanje dodatka cementa in superplastifikatorja je vplivalo na lastnosti pri mehanskem lomljenju betona v pozitivno in negativno smer. Iz tega izhaja, da je bilo treba nadzirati ne samo vpliv dodatka superplastifikatorja na tlačno trdnost, temveč tudi nameniti pozornost vrednostim parametrov pri prelomu. Odpornost proti stabilnem in nestabilnem napredovanju razpoke, ki je nedvoumno povezano z zdržljivostjo materiala, je bila ocenjena količinsko z uporabo dvojnega $K$-modela preloma.

Ključne besede: beton, parametri mehanskega preloma, superplastifikator, preizkus preloma, dvojni $K$-model

\section{INTRODUCTION}

The project of the Grant Agency of the Czech Republic "Assessment and Prediction of the Concrete Cover Layers Durability" deals with the study of problems of concrete cover layers' durability and contributes to the development of knowledge in the field of durability assessment and evaluation. The project is aimed especially at the determination of the transport characteristics of the concrete cover layers using the water- and gas-permeability methods. These so-called "durability parameters" are completed, especially with the fracture parameters (e.g., fracture toughness and fracture energy) and the basic physical and mechanical properties of fresh and hardened concrete ${ }^{1}$.

The quality of the surface layer is significantly related to the permeability of the material, which defines its transport properties, and the thermal and electrical conductivity. The permeability of the concrete with the dense aggregate depends mainly on the porosity of the cement stone structure and is affected, besides other things, by cracks with a width greater than $10^{-4} \mathrm{~m}$, resulting from the hardening of the concrete. Cracks (or microcracks) may combine together during the external loading of the concrete structure and create cracks, causing a significant reduction of durability or even serious failure of the structure. The connection of durability and content of the microcracks in the concrete is therefore obvious. The content of microcracks, and their resistance to stable and unstable propagation can be quantified by a number of fracture parameters.

In this paper the authors are focused on the mechanical fracture parameters obtained from records of three-point bending tests on concrete specimens with a central edge notch. The tests were conducted on four sets of specimens made of different materials. The concrete of the specimens was different in terms of the dosage of Portland cement CEM I 42.5 R and superplasticizer.

The resistance to stable and unstable crack propagation was quantified using the double- $K$ fracture model $^{2}$. Using this double- $K$ model it is possible to determine the critical crack-tip opening and the fracture toughness of the investigated concrete, and quantify - as indicated model name - two different levels of crack pro- 


\section{H. ŠIMONOVÁ et al.: THE EFFECT OF A SUPERPLASTICIZER ADMIXTURE ON THE MECHANICAL ...}

pagation: initiation, which corresponds to the beginning of the stable crack growth and the level of unstable crack propagation.

The results obtained using the double- $K$ model are completed by values of the compressive strength, the modulus of elasticity, the effective fracture toughness and the specific fracture energy.

\section{EXPERIMENTAL PART}

\subsection{Material}

The tests were conducted on four sets of specimens differing in terms of the material. The Portland cement CEM I 42.5 $\mathrm{R}$ was used as the binder. The aggregate consisted of three grain size fractions $(0-4,4-8$ and $8-16) \mathrm{mm}$. The superplasticizer Sika ViscoCrete 4035 was used in two mixtures in the amount of $0.25 \%$ of the weight of the cement. Table 1 introduces the details regarding the theoretical concrete mixtures' composition and their designation. Table 2 introduces the real concrete mixtures' composition. Table $\mathbf{3}$ introduces the properties of the fresh concrete, which were determined according Czech Standards ${ }^{3-6}$ in the laboratory at the concrete-mixing plant, when all four mixtures were

Table 1: Theoretical composition of the mixtures

Tabela 1: Teoretična sestava mešanic

\begin{tabular}{|l|c|c|c|c|}
\hline \multirow{2}{*}{\multicolumn{1}{|c|}{ Component }} & \multicolumn{4}{|c|}{ Mixture } \\
\cline { 2 - 5 } & $0 / 1$ & $1 / 1$ & $0 / 2$ & $1 / 2$ \\
\hline CEM I 42.5 R (kg) & 305 & 305 & 355 & 355 \\
\hline Sand 0-4 $(\mathrm{kg})$ & 929 & 951 & 886 & 923 \\
\hline Aggregate 4-8 (kg) & 182 & 186 & 182 & 186 \\
\hline Aggregate 8-16 (kg) & 690 & 706 & 690 & 706 \\
\hline Water (kg) & 200 & 185 & 209 & 180 \\
\hline Superplasticizer $(\mathrm{kg})$ & 0 & 0.76 & 0 & 0.89 \\
\hline
\end{tabular}

Table 2: Real composition of the mixtures

Tabela 2: Realna sestava mešanic

\begin{tabular}{|l|c|c|c|c|}
\hline \multirow{2}{*}{\multicolumn{1}{|c|}{ Component }} & \multicolumn{4}{c|}{ Mixture } \\
\cline { 2 - 5 } & $0 / 1$ & $1 / 1$ & $0 / 2$ & $1 / 2$ \\
\hline CEM I 42.5 R (kg) & 309 & 303 & 358 & 359 \\
\hline Sand 0-4 (kg) & 927 & 952 & 892 & 921 \\
\hline Aggregate 4-8 (kg) & 182 & 190 & 175 & 190 \\
\hline Aggregate 8-16 (kg) & 698 & 707 & 695 & 712 \\
\hline Water (kg) & 202 & 149 & 192 & 170 \\
\hline Superplasticizer (kg) & 0 & 0.73 & 0 & 0.93 \\
\hline
\end{tabular}

Table 3: Properties of fresh concrete

Tabela 3: Lastnosti svežega betona

\begin{tabular}{|l|c|c|c|c|}
\hline \multirow{2}{*}{\multicolumn{1}{c|}{ Property }} & \multicolumn{4}{c|}{ Mixture } \\
\cline { 2 - 5 } & $0 / 1$ & $1 / 1$ & $0 / 2$ & $1 / 2$ \\
\hline Density $\left(\mathrm{kg} / \mathrm{m}^{3}\right)$ & 2315 & 2275 & 2315 & 2300 \\
\hline Slump test $(\mathrm{mm})$ & 60 & 60 & 60 & 50 \\
class & $\mathrm{S} 2$ & $\mathrm{~S} 2$ & $\mathrm{~S} 2$ & $\mathrm{~S} 2$ \\
\hline Flow test $(\mathrm{mm})$ & 410 & 360 & 385 & 350 \\
class & $\mathrm{F} 2$ & $\mathrm{~F} 2$ & $\mathrm{~F} 2$ & $\mathrm{~F} 2$ \\
\hline Air content $(\%)$ & 2.7 & 3.6 & 2.5 & 2.8 \\
\hline
\end{tabular}

prepared. The consistency class of the fresh concrete determined using the slump test and the flow-table test was the same for all the mixtures (Table 3).

\subsection{Testing procedure}

Beam specimens (of nominal dimensions $100 \mathrm{~mm} \times$ $100 \mathrm{~mm} \times 400 \mathrm{~mm}$ ) with a central edge notch were subjected to three-point bending fracture tests (Figure 1). The notches were made before testing with a diamond blade saw. The notch depth was approximately equal to $1 / 3$ of the depth of the specimen. The span length was equal to $300 \mathrm{~mm}$. Three specimens from each set were tested after aging for $28 \mathrm{~d}$. The fracture tests were carried out using a Heckert FPZ 100/1 testing machine (Figure 2) with the load range of $0-10 \mathrm{kN}$.

Load versus deflection diagrams $(P-d$-diagrams) and load versus crack mouth opening diagrams $(P-$ $C M O D$-diagrams) were recorded using induction sensors and an extensometer (crack-opening displacement transducer) connected in a HBM SPIDER 8 device during the fracture experiments.

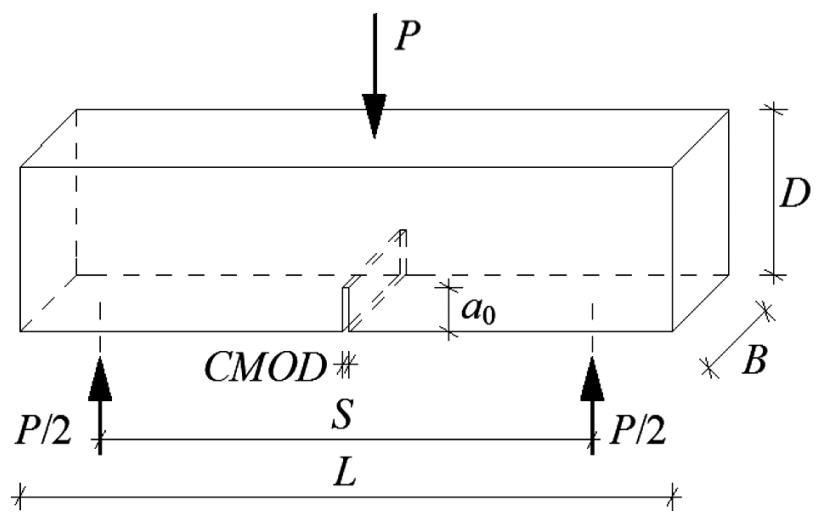

Figure 1: Three-point bending fracture test geometry

Slika 1: Geometrija vzorca za tritočkovni upogibni preizkus

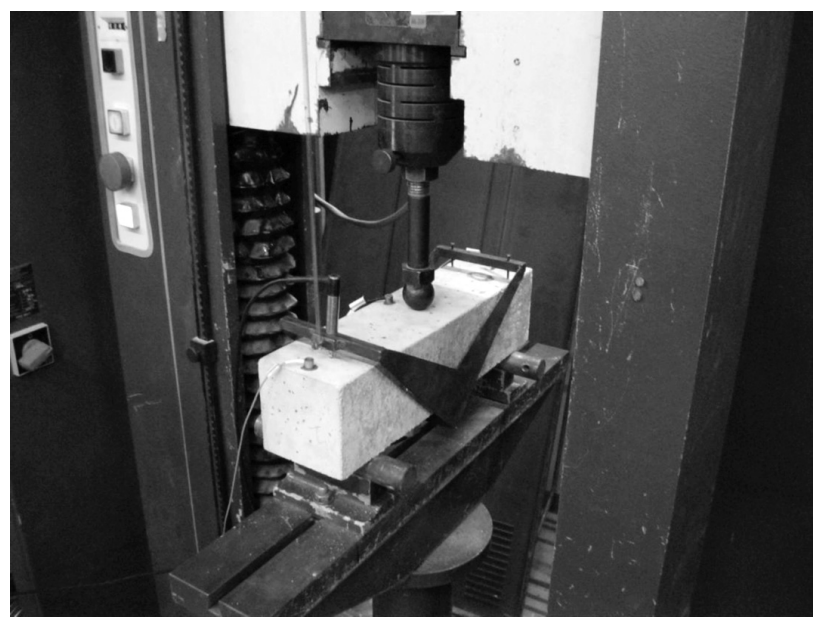

Figure 2: Fracture-test configuration in testing machine Slika 2: Priprava preizkusa preloma na preizkusni napravi 
Cubes with edge lengths of $150 \mathrm{~mm}$ were used for the determination of the compressive strength values. The compressive tests were carried out using a FORM+TEST ALPHA 3-3000 testing machine with the load range $0-3000 \mathrm{kN}$. The compressive strength tests were performed according to the Czech standard ČSN EN 12 390-37; the loading rate was $0.6 \mathrm{MPa} / \mathrm{s}$.

\subsection{Methods}

The modulus of elasticity values were obtained from the first (almost) linear part of the corrected $P-d$-diagrams. The effective fracture toughness was determined using the Effective Crack Model ${ }^{8}$, which combines linear elastic fracture mechanics and the crack-length approach. Estimations of the fracture energy values according to the RILEM method were calculated using a "work of fracture" value 9 . Note that, especially in the case of the plain concrete specimens, a stability loss during the displacement-controlled loading can occur due to the low rigidity of the loading set-up. This stability loss appears as a jump in the measured parameters. A procedure was developed to recognise this problem and correct it in the case of fracture tests conducted on concrete specimens ${ }^{10}$.

The measured $P-C M O D$-diagrams were used to determine the fracture parameters of the double- $K$ model. Two levels of crack propagation were quantified: the initiation of stable crack growth and the level of unstable crack propagation.

The unstable fracture toughness $K_{\text {Ic }}{ }^{\text {un }}$ was numerically determined first, followed by the cohesive fracture toughness $K_{\mathrm{Ic}}{ }^{\mathrm{c}}$. When both of these values are known, the following formula can be used to calculate the initiation fracture toughness $K_{\mathrm{Ic}}{ }^{\mathrm{ini}}$ :

$$
K_{\text {Ic }}^{\text {ini }}=K_{\text {Ic }}^{\text {un }}-K_{\text {Ic }}^{\mathrm{c}}
$$

Details regarding the calculation of both the unstable and cohesive fracture toughness can be found, e.g., in the following articles ${ }^{11,12}$.

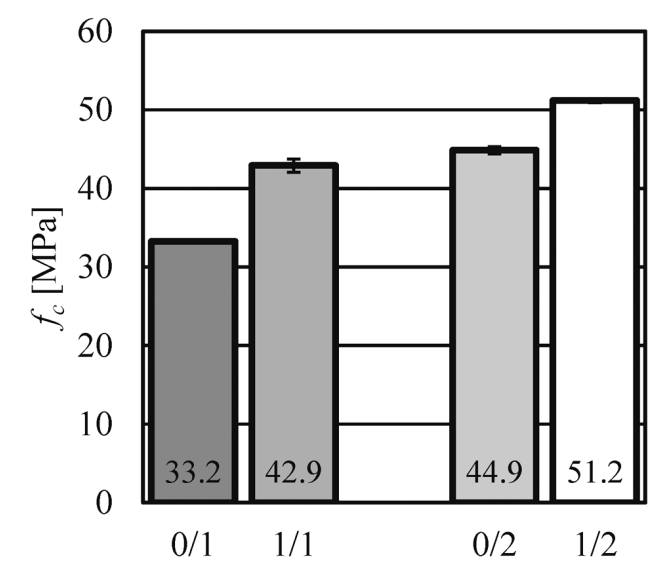

Figure 3: Comparison of the compressive strength values $f_{c}$ of the concrete sets

Slika 3: Primerjava vrednosti tlačne trdnosti $f_{\mathrm{c}}$ za skupine betonov
Finally, in accordance with Equation (2) the value of the load $P_{\text {ini }}$ is determined. This value can be defined as the load level at the beginning of stable-crack propagation from an initial crack/notch and can be obtained using the expression ${ }^{1}$ :

$$
P_{\text {ini }}=\frac{4 W K_{\mathrm{Ic}}^{\mathrm{ini}}}{S F_{1}\left(\alpha_{0}\right) \sqrt{a_{0}}}
$$

where $W=1 / 6 B D^{2}$ is the section modulus, $B$ is the specimen width, $D$ is the specimen depth, $S$ is the load span, $a_{0}$ is the initial notch length according to Figure $\mathbf{1}$ and $F_{1}\left(\alpha_{0}\right)$ is the geometry function given by the following equation:

$$
F_{1}\left(\alpha_{0}\right)=\frac{1.99-\alpha_{0}\left(1-\alpha_{0}\right)\left(2.15-3.93 \alpha_{0}+2.7 \alpha_{0}^{2}\right)}{\left(1+2 \alpha_{0}\right)\left(1-\alpha_{0}\right)^{3 / 2}}
$$

where $\alpha_{0}$ is the ratio $a_{0} / D$.

\section{RESULTS}

The arithmetic mean and the standard deviation values of the selected parameters are introduced in following figures: compressive strength $f_{\mathrm{c}}$ (Figure 3), elasticity modulus $E_{\mathrm{c}}$ (Figure 4), specific fracture energy $G_{\mathrm{F}}$ (Figure 5), effective fracture toughness $K_{\text {Ice }}$ (Figure 6), initiation level of the stress intensity factor $K_{\mathrm{Ic}}{ }^{\mathrm{ini}}$ (Figure 7), ratio $K_{\mathrm{Ic}}{ }^{\mathrm{ini}} / K_{\mathrm{Ic}}{ }^{\text {un }}$ (Figure 8), i.e., the ratio of the initiation fracture toughness to unstable fracture toughness, and the ratio $P_{\text {ini }} / P_{\max }$ (Figure 9), i.e., the ratio between the force at the beginning of stable-crack propagation from an initial stress concentrator and the maximum force corresponding to the peak of the $P$ CMOD-diagram.

The relative mean values of these properties are introduced in Table 4 - the $100 \%$ value for each material parameter represents the values of this parameter for the concrete with same amount of cement without superplasticizer.

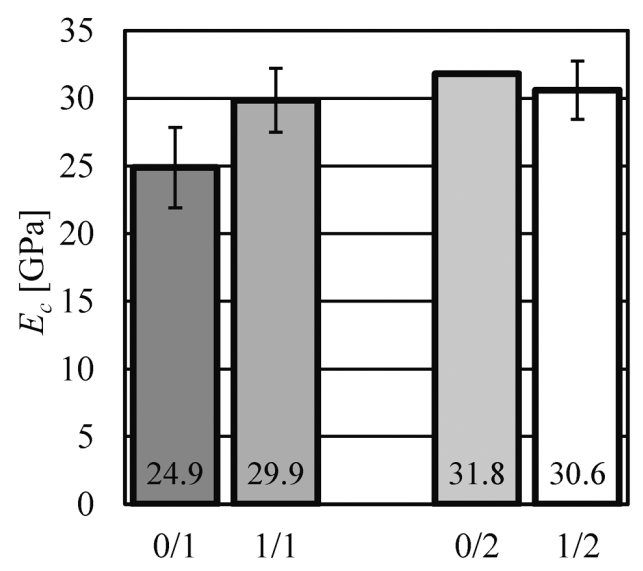

Figure 4: Comparison of the modulus elasticity values $E_{\mathrm{c}}$ of the concrete sets

Slika 4: Primerjava vrednosti modula elastičnosti $E_{\mathrm{c}}$ za skupine betonov 
H. ŠIMONOVÁ et al.: THE EFFECT OF A SUPERPLASTICIZER ADMIXTURE ON THE MECHANICAL ...

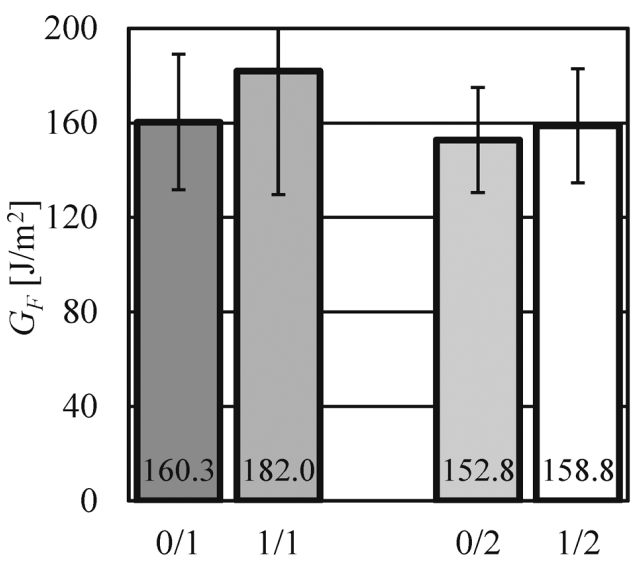

Figure 5: Comparison of the specific fracture energy $G_{\mathrm{F}}$ of the concrete sets

Slika 5: Primerjava specifične prelomne energije $G_{\mathrm{F}}$ za skupine betonov

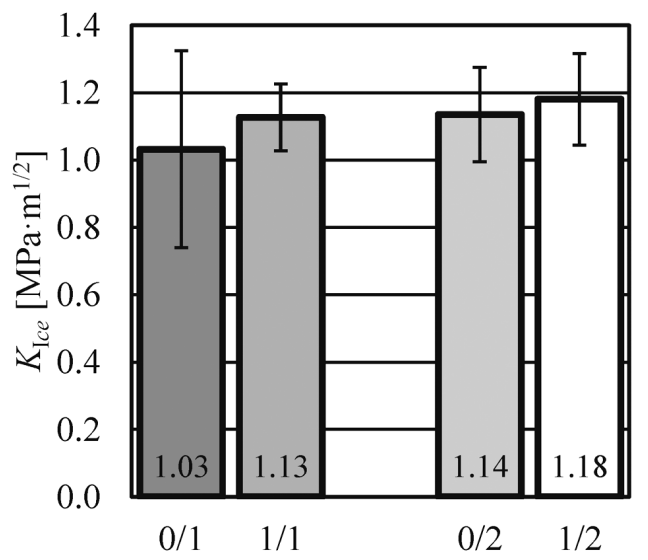

Figure 6: Comparison of the effective fracture toughness $K_{\text {Ice }}$ of the concrete sets

Slika 6: Primerjava efektivne lomne žilavosti $K_{\text {Ice }}$ za skupine betonov

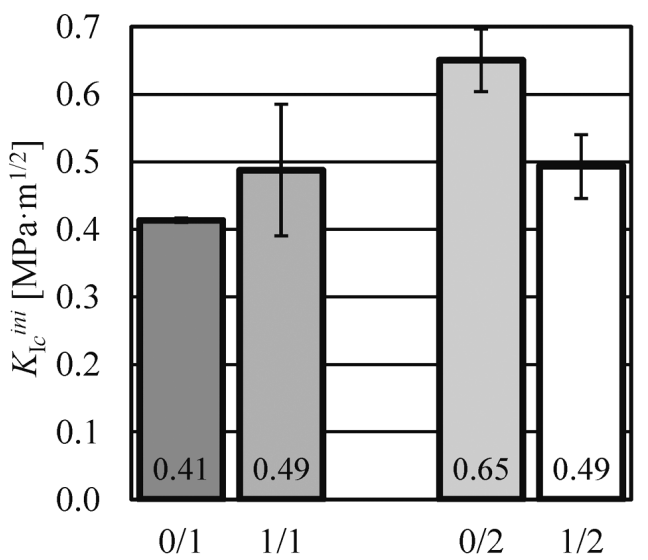

Figure 7: Comparison of the initiation level of stress intensity factor $K_{\text {Ic }}{ }^{\text {ini }}$ of the concrete sets

Slika 7: Primerjava iniciacijskega nivoja napetostnega intenzitetnega faktorja $K_{\mathrm{Ic}}{ }^{\text {ini }}$ za skupine betonov

The concrete with the superplasticizer admixture achieved higher compressive strength values for both dosages of cement - concrete $1 / 1$ had about $30 \%$ higher value of compressive strength than concrete $0 / 1$ without

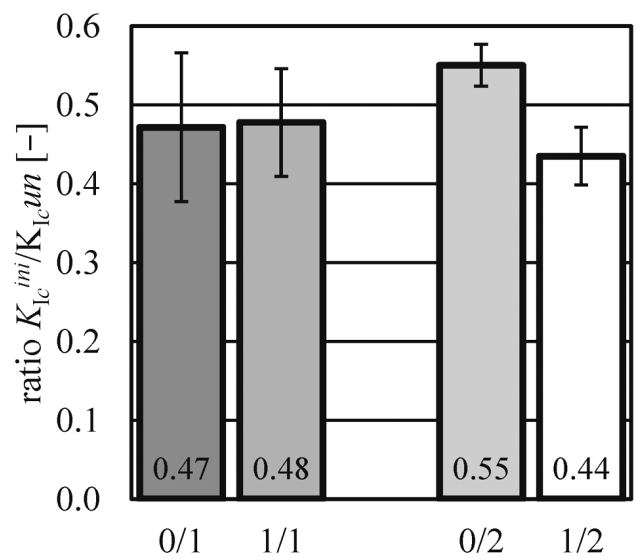

Figure 8: Comparison of the ratio $K_{\mathrm{Ic}}{ }^{\mathrm{ini}} / K_{\mathrm{Ic}}{ }^{\text {un }}$ of the concrete sets Slika 8: Primerjava razmerij $K_{\mathrm{Ic}}{ }^{\mathrm{ini}} / K_{\mathrm{Ic}}{ }^{\text {un }}$ za skupine betonov

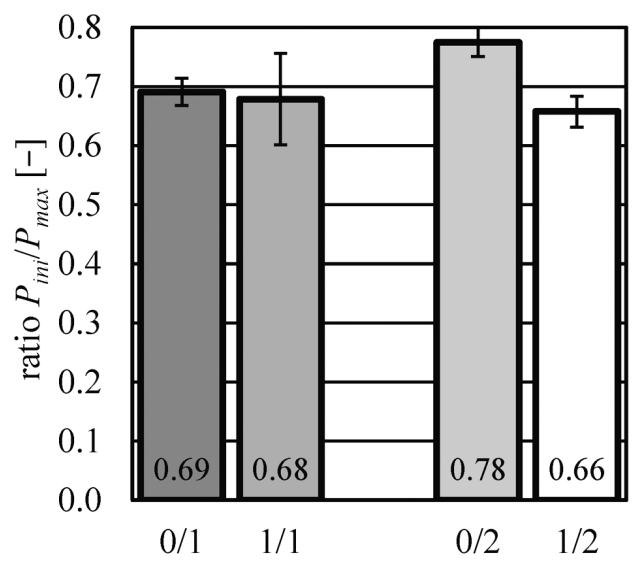

Figure 9: Comparison of the ratio $P_{\text {ini }} / P_{\max }$ of the concrete sets Slika 9: Primerjava razmerja $P_{\text {ini }} / P_{\max }$ za skupine betonov

Table 4: The relative mean values of selected parameters of concrete sets in \%

Tabela 4: Relativne glavne vrednosti izbranih parametrov vrst betona v $\%$

\begin{tabular}{|l|c|c|c|c|}
\hline \multirow{2}{*}{\multicolumn{1}{|c|}{ Parameter }} & \multicolumn{4}{c|}{ Concrete } \\
\cline { 2 - 5 } & $0 / 1$ & $1 / 1$ & $0 / 2$ & $1 / 2$ \\
\hline$f_{\mathrm{c}} / \mathrm{MPa}$ & 100 & 129.1 & 100 & 114.0 \\
\hline$E_{\mathrm{c}} / \mathrm{GPa}$ & 100 & 120.1 & 100 & 96.2 \\
\hline$G_{\mathrm{F}} / \mathrm{J} / \mathrm{m}^{2}$ & 100 & 113.5 & 100 & 103.9 \\
\hline$K_{\mathrm{Ice}} /\left(\mathrm{MPa} \mathrm{m}^{1 / 2}\right)$ & 100 & 109.1 & 100 & 104.0 \\
\hline$K_{\mathrm{Ic}}{ }^{i n i} /\left(\mathrm{MPa} \mathrm{m}^{1 / 2}\right)$ & 100 & 117.9 & 100 & 75.8 \\
\hline$K_{\mathrm{Ic}}{ }^{\mathrm{ini}} / K_{\mathrm{Ic}}{ }^{\text {un }}$ & 100 & 101.3 & 100 & 79.0 \\
\hline$P_{\mathrm{ini}} / P_{\max }$ & 100 & 98.2 & 100 & 84.9 \\
\hline
\end{tabular}

superplasticizer, and the concrete $1 / 2$ was about $15 \%$ higher than concrete $0 / 2$.

The values of the modulus of elasticity also increased with a superplasticizer admixture in the case of a lower dosage of cement - concrete $1 / 1$ achieved an about $20 \%$ higher value of this parameter than the concrete $0 / 1$. On the other hand, the modulus of elasticity values decreased in the case of concrete $1 / 2$ in comparison with the concrete $0 / 2$ by about $4 \%$ - but the variability is higher in the case of concrete $1 / 2$, so we could say that the superplasticizer admixture had no effect on the elasti- 
city modulus value in the case of a higher dosage of cement.

The fracture energy quantifies the brittleness/toughness of the material through the evaluation of the whole $P-d$-diagram. This parameter value increased with the superplasticizer admixture in both cases of cement dosage. In addition, these values decreased with an increase of the cement dosage in both cases of concrete, with or without the superplasticizer. The variability of the results is relatively high.

The effective fracture toughness takes into consideration the brittleness/toughness of the materials through the encompassing nonlinearity of the $P-d$-diagram before reaching the peak load. This parameter value has probably slightly increased with the superplasticizer admixture in both cases of the cement dosage, but the variability of the results is quite high - concrete $1 / 1$ had an about $10 \%$ higher value than the concrete $0 / 1$ without the superplasticizer, and the concrete $1 / 2$ had an about 5 $\%$ higher value than concrete $0 / 2$.

The initiation fracture-toughness value increased with the superplasticizer admixture in the case of the lower dosage of cement - concrete $1 / 1$ achieved an about $20 \%$ higher value for this parameter than concrete $0 / 1$. On the other hand, this parameter decreased in the case of concrete $1 / 2$ in comparison with concrete $0 / 2$ by about $25 \%$.

The relative value of the stress-intensity factor for the the initiation of stable crack growth from the initial notch quantifies the initiation brittleness/toughness of the material corresponding to the loss of linearity of the $P$ $C M O D$-diagram before reaching the peak load. This parameter value did not change with the superplasticizer admixture presence for a lower dosage of cement. On the other hand, this parameter decreased in the case of concrete $1 / 2$ in comparison with concrete $0 / 2$ by about $20 \%$. Similar results were achieved for the ratio between the force at the beginning of the stable-crack propagation from an initial stress concentrator and the maximum force corresponding to the peak of the $P-C M O D$-diagram.

\section{CONCLUSIONS}

The authors focused their attention on the mechanical fracture parameters determined via the evaluation of the records of the experiments performed on four sets of concrete specimens with the stress concentrator. The concrete used in each set differed in terms of the dosage of Portland cement and superplasticizer. Increasing the dosage of cement and superplasticizer admixture influences the mechanical fracture properties of the concrete in both positive and negative ways. It follows that it is proper to monitor not only the effect of superplasticizer admixture on the compressive strength values ${ }^{13,14}$, but also focus attention on the fracture parameter values. Particularly in the case of a higher dosage of cement the superplasticizer admixture presence had a negative effect on the values of the fracture parameters that quantify the resistance to stable and unstable crack propagation.

\section{Acknowledgement}

This research was carried out with the financial support of the Czech Science Foundation, project GA CR 13-18870S and the European Union's "Operational Programme Research and Development for Innovations", No. CZ.1.05/2.1.00/03.0097 as an activity of the regional Centre AdMaS "Advanced Materials, Structures and Technologies".

\section{REFERENCES}

${ }^{1}$ A. M. Nevile, Properties of Concrete, Pearson Education Limited, Harlow 2011, 846

${ }^{2}$ S. Kumar, S. V. Barai, Concrete Fracture Models and Applications, Springer, Berlin 2011, 406

${ }^{3}$ ČSN EN 12350-2 Testing fresh concrete - Part 2: Slump-test, Czech Standards Institute, 2009. (This standard is the Czech version of the European Standard EN 12350 -2: 2009)

${ }^{4}$ ČSN EN 12350-5 Testing fresh concrete - Part 5: Flow table test, Czech Standards Institute, 2009, (This standard is the Czech version of the European Standard EN 12350 -5: 2009)

${ }^{5}$ ČSN EN 12350-6 Testing fresh concrete - Part 6: Density, Czech Standards Institute, 2009 (This standard is the Czech version of the European Standard EN 12350 -6: 2009)

${ }^{6}$ ČSN EN 12350-6 Testing fresh concrete - Part 7: Air content Pressure methods, Czech Standards Institute, 2009, (This standard is the Czech version of the European Standard EN 12350-7: 2009)

${ }^{7}$ ČSN EN 12390-3 Testing hardened concrete - Part 3: Compressive strength of test specimens, Czech Standards Institute, 2009, (This standard is the Czech version of the European Standard EN 12390-3: 2009)

${ }^{8}$ B. L. Karihaloo, Fracture Mechanics and Structural Concrete, Longman Scientific \& Technical, New York 1995, 346

${ }^{9}$ RILEM TC-50 FMC (Recommendation): Determination of the fracture energy of mortar and concrete by means of three-point bend test on notched beams, Materials \& Structures, 18 (1985), 285-290

${ }^{10}$ P. Frantík, J. Průša, Z. Keršner, J. Macur, About stability loss during displacement-controlled loading, Proc. of Inter. Conf. on Fibre Concrete 2007, Prague, 2007

${ }^{11}$ S. Xu, H. W. Reinhardt, Z. Wu, Y. Zhao, Otto-Graf-Journal, 14 (2003), 131-157

${ }^{12}$ X. Zhang, S. Xu, Engineering Fracture Mechanics, 78 (2011), 2115-2138, doi:10.1016/j.engfracmech.2011.03.014

${ }^{13}$ M. Mittal, S. Basu, A. Sofi, International Journal of Civil Engineering, 2 (2013) 4, 61-66

${ }^{14}$ S. M. A. El-Gamal, F. M. Al-Nowaiserb, A. O. Al-Baityb, Journal of Advanced Research, 3 (2012) 2, 119-124, doi:10.1016/j.jare. 2011.05.008 